Institute of $\mathbf{F}_{\text {ood and }} \mathbf{A}_{\text {gricultural }} \mathbf{S}_{\text {ciences }}$

\title{
Market Development Strategies for Florida Fresh Sweet Corn: Findings from a Consumer Survey, 20011
}

Tom Stevens, Robert Degner, Kimberly Morgan, Chris deBodisco, and Lisa House ${ }^{2}$

\section{Introduction}

Florida is the leading producer of fresh sweet corn in the United States. In 2000, 573 million pounds of fresh sweet corn were harvested from over 38,000 acres in the State, generating revenues of over $\$ 105$ million. During spring 2000, 81 percent of the U.S. fresh sweet corn shipments originated from Florida (Figure 1). For the nation, fresh sweet corn has become an increasingly popular spring and summer side dish. The introduction of super sweet varieties in the early 1990s helped boost annual per-capita consumption from 5.9 pounds in 1991 to 9.2 pounds in 2000 , an increase of more than 66 percent. However, in spite of its premier status in the industry and the overall growth of fresh sweet corn production and consumption, Florida's future leadership in the industry is not guaranteed. Fresh sweet corn production and real revenues for the State have not shown any overall trend in the 10 years between 1991 and 2001 (Figure 2). Also, during this period, yields increased, while acreage declined, and real free-on-board (FOB) prices fluctuated trendlessly around $\$ 9.00$ per crate. Most disturbing is the fact that while constant dollar receipts for fresh sweet corn in the United States rose by over 68 percent between 1992 and 2001, Florida's share of these receipts declined from 27 percent to less than 23 percent (Figure 3).

Growers from Florida formed the Fresh Supersweet Corn Council (formerly Southern SuperSweet Corn Council) to facilitate market research and development. Council members represent the majority of the sweet corn shipped and consumed in the United States from late fall through early summer. From 1998 through 2001, the Council promoted fresh sweet corn directly to consumers through a third-party communications agency. In 2001, the Council contracted with the Florida Agricultural Market Research Center at the Institute of Food and Agricultural Sciences to conduct a consumer survey to evaluate existing and potential impediments to future market growth for both wholesale and retail stages and to make recommendations for specific marketing strategies that could increase Council members' profitability. The following discussion briefly reviews the procedures and findings of that analysis.

1. This is EDIS document FE377, a publication of the Department of Food and Resource Economics, Florida Cooperative Extension Service, Institute of Food and Agricultural Sciences, University of Florida, Gainesville, FL. Published March 2003. Please visit the EDIS website at http://edis.ifas.ufl.edu.

2. Tom Stevens, Post-Doctoral Associate; Robert Degener, Professor; Kimberly Morgan, Economic Analyst; Chris deBodisco, Graduate Assistant; and Lisa House, Associate Professor, Department of Food and Resource Economics, Florida Cooperative Extension Service, Institute of Food and Agricultural Sciences, University of Florida, Gainesville, FL.

The Institute of Food and Agricultural Sciences is an equal opportunity/affirmative action employer authorized to provide research, educational information and other services only to individuals and institutions that function without regard to race, color, sex, age, handicap, or national origin. For information on obtaining other extension publications, contact your county Cooperative Extension Service office. Florida Cooperative Extension Service/Institute of Food and Agricultural Sciences/University of Florida/Christine Taylor Waddill, Dean. 


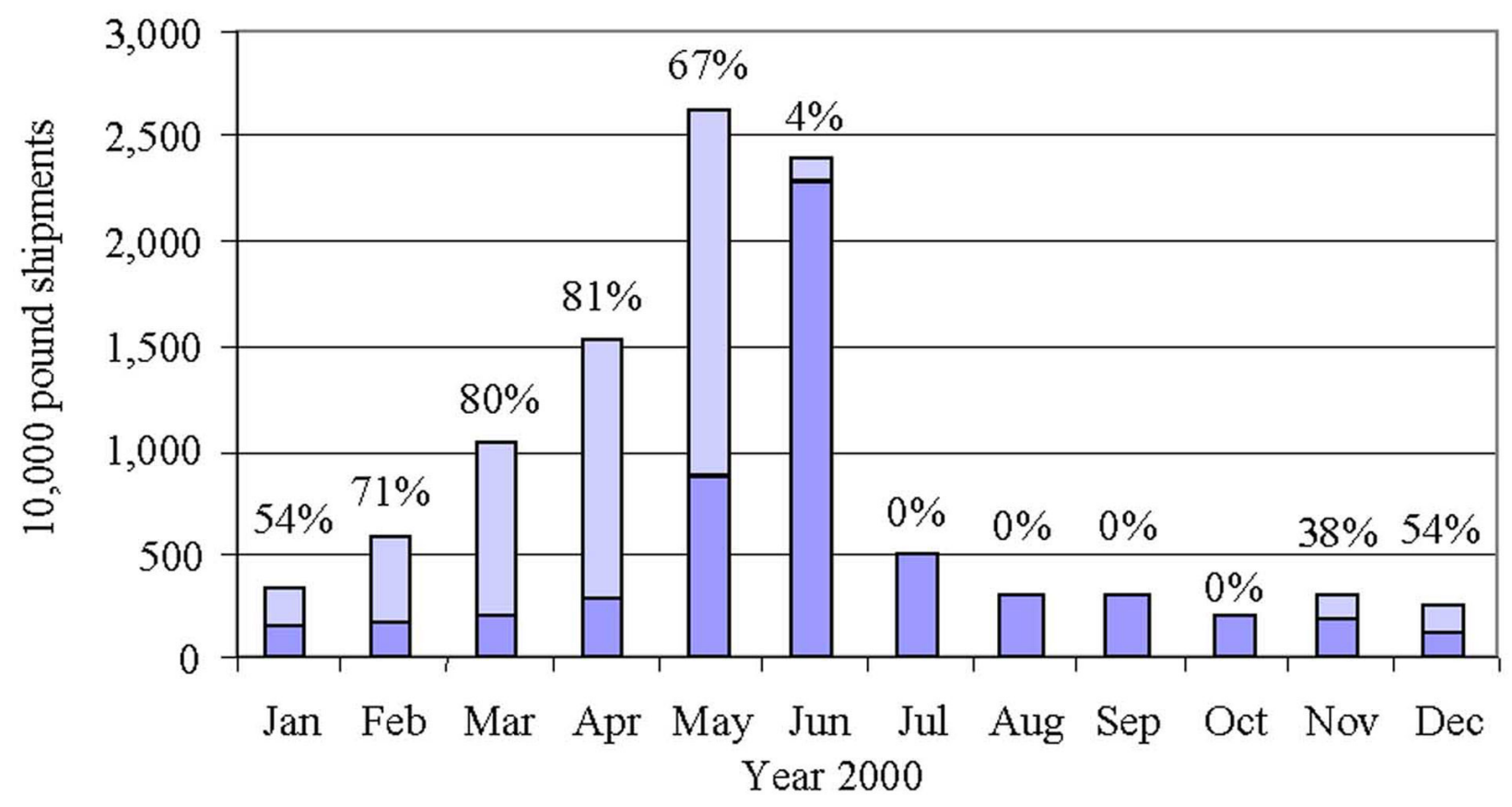

$\square$ Other states and imports $\square$ Florida and \% Florida

CREDITS: USDA-AMS, Fruit and Vegetable Program, Market News Branch. "Fresh Fruit and Vegetable Shipments", FVAS-4, 2000.

Figure 1. U.S. fresh sweet corn shipments, 2000.

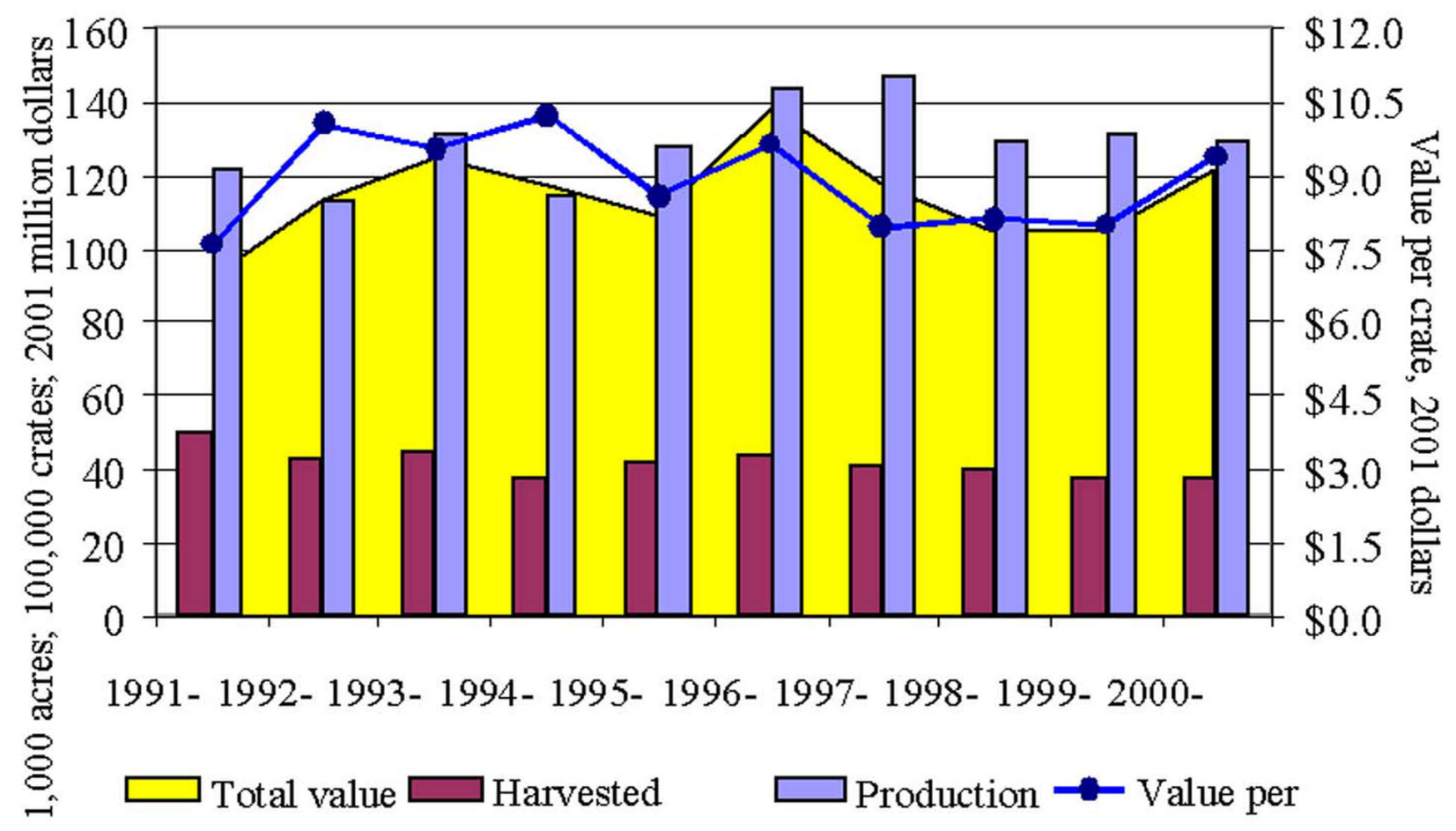

CREDITS: Florida Agricultural Statistics Service, USDA-NASS, Florida Agricultural Facts, 2002.

Figure 2. Florida fresh sweet corn value, 1991-2001. 


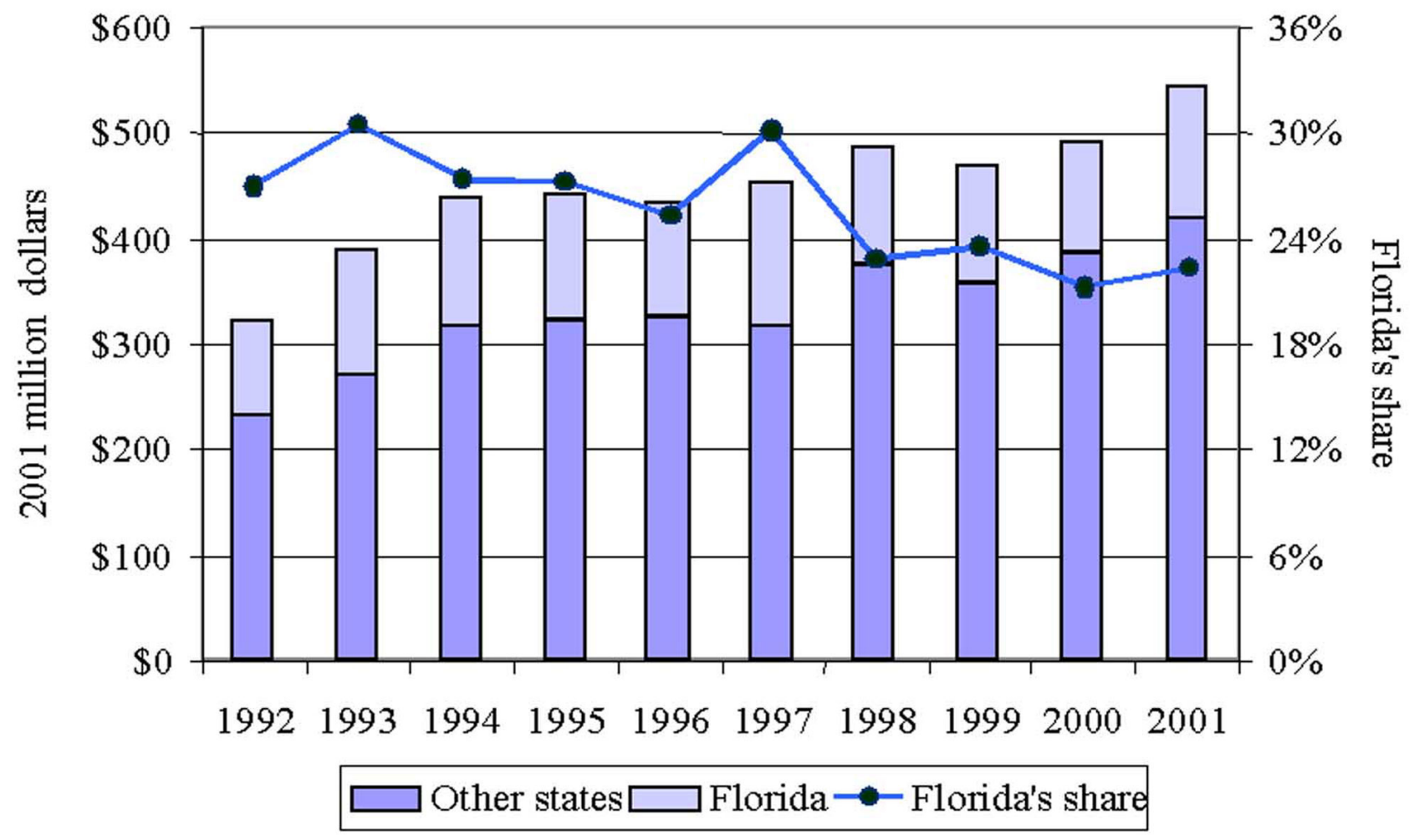

CREDITS: USDA-ERS, U.S. and State Farm Income Database.

Figure 3. U.S. fresh sweet corn receipts, 1992-2001.

\section{Objectives and Procedures}

The specific objectives of the consumer-level component of the fresh sweet corn marketing study were to identify and evaluate various consumer perceptions, characteristics, usage patterns, and information sources related to fresh sweet corn purchases. Telephone interviews of 1,031 primary food shoppers residing in five major metropolitan areas (Dallas, Chicago, Atlanta, Philadelphia, and Boston) were conducted between September and November of 2001. These cities were selected because of their socio-economic and ethnic diversity. The questionnaire was pre-tested to assure its functionality and to help remove any ambiguities. Households were selected using a random digit telephone dialing technique. When necessary, each household was contacted during different times of the day, a minimum of six times each, to avoid any statistical bias cuased by over-sampling of non-working food shoppers.

\section{Findings}

The findings are focused on factors that limit the consumption of fresh sweet corn and on the differences in usage among various types of consumers. Of the 1,031 interviewed households, 698, or 67.7 percent, were found to buy fresh sweet corn at least once each year. Among non-consumers, the most cited reason (30 percent) for not buying fresh sweet corn was that they did not like the taste (Table 1). Twenty-two percent of non-consumers were concerned with the amount of preparation time or inconvenience, and an additional seven percent thought that fresh sweet corn was too messy. Other reasons cited for not buying fresh sweet corn included not fresh (eight percent), do not know how to cook (seven percent), and prefer canned or frozen (seven percent), and dental problems (five percent).

Notably, price was not an important consideration for non-buyers. Only three percent of the non-consumers mentioned price too high as a reason not to buy fresh sweet corn. 
An analysis of demographic differences in fresh sweet-corn consumption revealed that the proportion of sweet corn buyers increased with education, income, household size, and number of children (Figure 4). No statistical differences were found in the proportion of respondents purchasing fresh sweet corn among the five cities in the survey, nor did race or ethnicity affect the likelihood of a consumer being a sweet corn buyer (Figure 5). Middle-aged consumers were found to be more likely to buy sweet corn than young or retirement-age consumers. Only 56 percent of the respondents in the 18-to-34 age group bought sweet corn, as compared to 82 percent of those in the 50-to-64 age group (Figure 5).
70 percent of the winter "non-buyers" cited lack of availability, as compared to about 57 percent of the spring non-buyers and 63 percent of the fall non-buyers (Figure 6). Understanding and addressing the reasons why consumers do not purchase fresh sweet corn during these nontraditional seasons is key to improving year-round market share for Florida producers.

Consumers did not express a strong preference for, or awareness of, any particular variety of fresh sweet corn. Only 16.5 percent of those who bought fresh sweet corn indicated a preference for any specific variety. Many respondents referred to a store

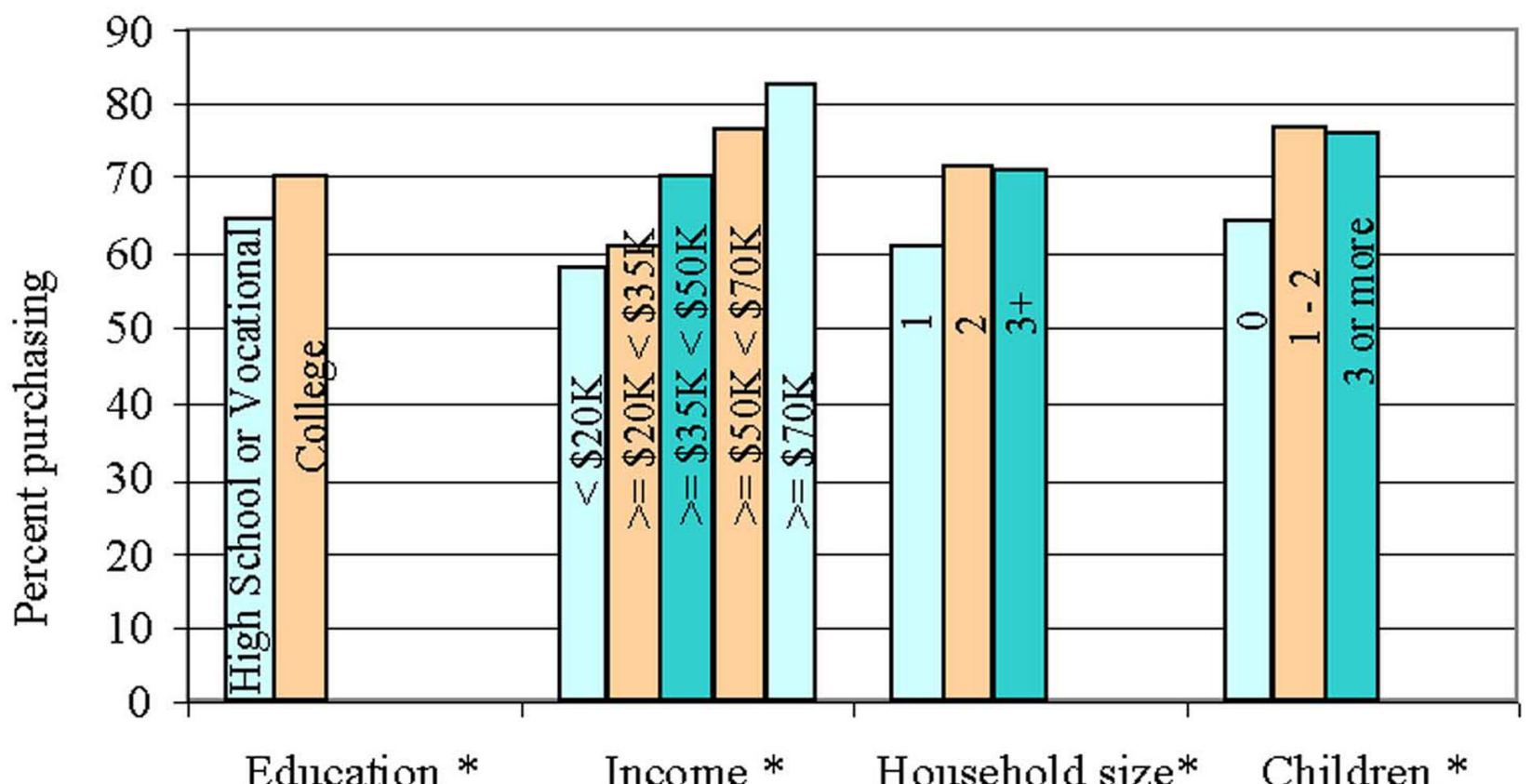

CREDITS: USDA-ERS, U.S. and State Farm Income Database. *Indicates differences in responses between groups are statistically significant.

Figure 4. Percentage of consumers purchasing fresh sweet corn (education, income, household size, number of children).

Substantial seasonal differences were discovered in the proportion of households buying sweet corn (Figure 5). Virtually all households consuming fresh sweet corn purchased it in the summer, but only 36 percent bought it in the winter. Seventy-one percent of households purchased fresh sweet corn in the spring, while only 49 percent did so in the fall. When respondents who said they did not buy fresh sweet corn during the winter, spring, and fall seasons were asked for the "main reason" why they did not do so, the overwhelming majority said that it was not available where they usually shop for produce. Nearly name when asked about their preferences for a specific variety of fresh sweet corn. The name "Southern Supersweet" was mentioned as a preferred "variety" by less than one percent of all the interviewed fresh sweet corn buyers.

Significant differences in color preference were found to be associated with respondents' location, race, and income. Consumers in Dallas and Chicago expressed strong preferences for yellow corn (62 percent), while those in Philadelphia showed a marked preference for white corn (52 percent) over 


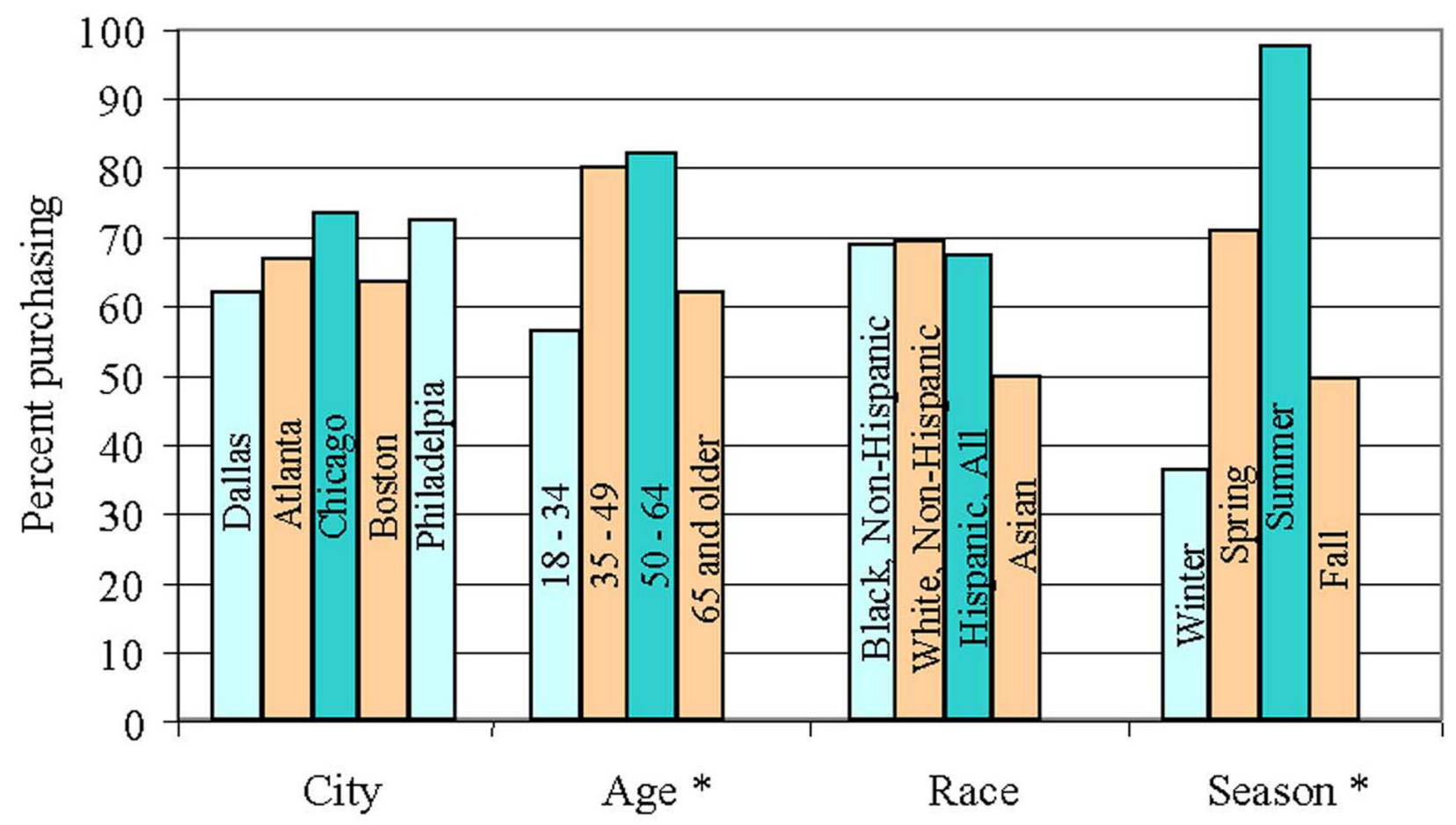

CREDITS: Study survey. *Indicates differences in responses between groups are statistically significant

Figure 5. Percentage of consumers purchasing fresh sweet corn (city, age, race, education).

yellow corn (39 percent). With respect to economics, consumers' preference for yellow corn decreases as their income levels rise. From a racial and ethnicity perspective, Asians, Hispanics, and Blacks indicated a very clear preference for yellow corn. The most important reason given for any color preference was perceived superior taste. This is especially true for white and bicolor fresh sweet corn buyers (over 62 percent), who also mentioned "sweeter" twice as frequently as yellow corn buyers. "Habit" was one reason frequently mentioned by yellow-corn buyers (26 percent) that was not an important reason mentioned by buyers who purchased other colors (five to seven percent). "Appealing Color" was important to those buying bicolor corn (21 percent) and yellow corn (18 percent).

Overall, nearly 75 percent of fresh sweet corn consumers prefer to purchase it "loose" or in bulk and unshucked. Sixteen percent of respondents preferred to purchase fully-shucked and pre-packaged fresh sweet corn, while about nine percent preferred a partially-shucked, pre-packaged product. In general, more than 83 percent of fresh sweet corn consumers prefer to shuck their purchases at home. The majority of buyers (almost 62 percent) prefer to purchase unrefrigerated fresh sweet corn from their retail outlets. Forty-six percent of all fresh sweet corn purchasers store it shucked. Boiling is the predominant method for cooking fresh sweet corn (over 70 percent). Other methods of cooking (e.g., microwaving) are not heavily used.

About 37 percent of all fresh sweet corn purchasers said they had seen newspaper feature stories and newspaper food advertisements for fresh sweet corn within the past year. Approximately 30 percent recalled seeing store posters and television features such as cooking shows. Only seven percent of all fresh sweet corn buyers had ever received any information about the availability, nutritional qualities, or cooking methods for fresh sweet corn. The four most common informational sources included cookbooks, magazine articles, word-of-mouth recommendations, and newspaper articles. Consumers had seen magazine ads (22 percent) and magazine feature stories (15 percent) on fresh sweet corn. 


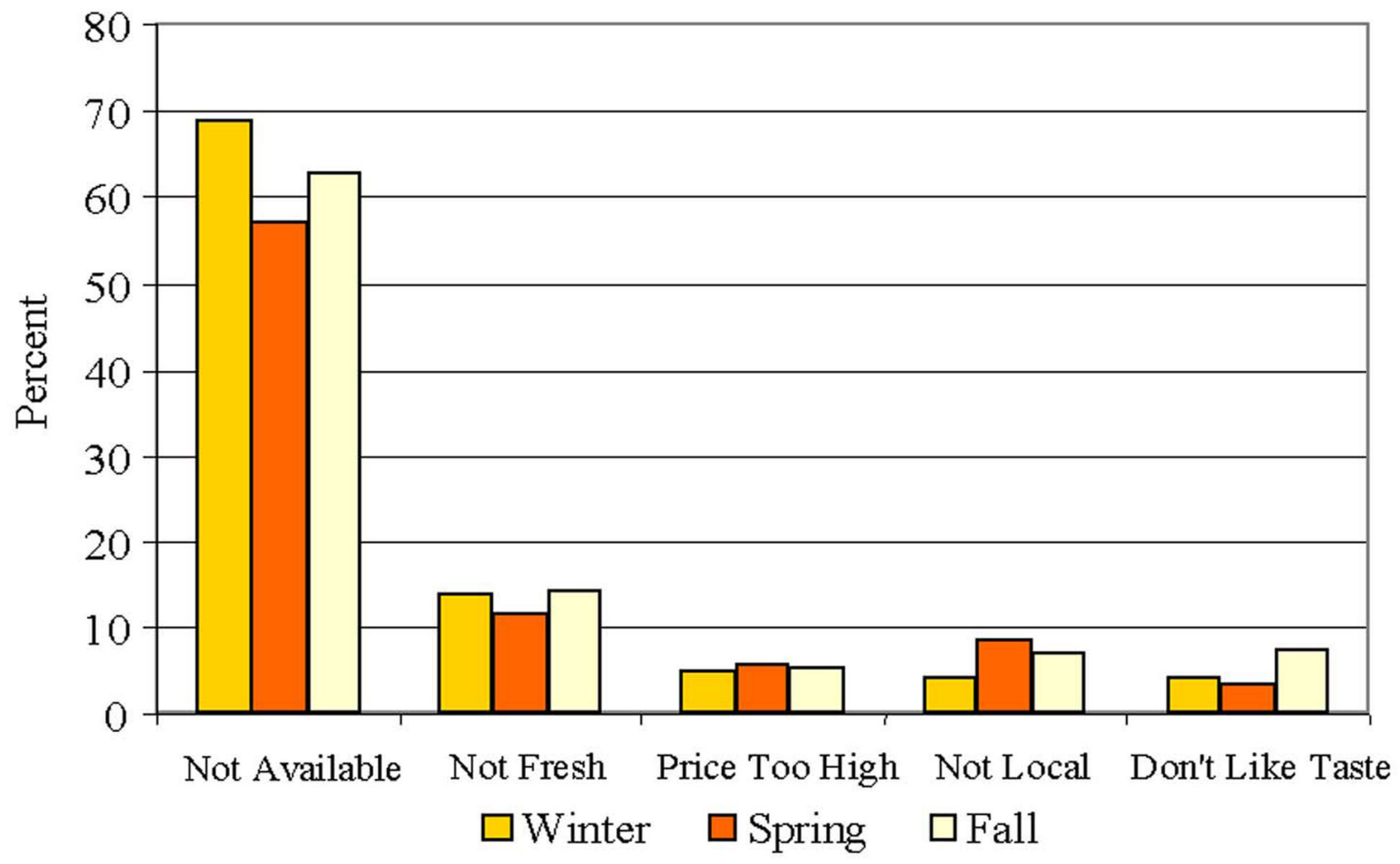

CREDITS: Study survey. *Indicates differences in responses between groups are statistically significant.

Figure 6. Major reasons for not buying, by season.

\section{Conclusions and Recommendations}

The most important finding of the consumer survey was that there is very limited consumption of fresh sweet corn in the winter, spring, and fall seasons, primarily due to consumer belief that sweet corn is unavailable during these seasons. With adequate educational and promotional efforts, this misperception can be alleviated. Consumer educational programs should be expanded using timely television feature stories, news releases targeted at newspaper food editors, consumer magazine feature stories, and a Southern Supersweet Internet website. Some of this educational effort should also be directed to creating greater awareness in the retail trade by providing promotional materials that could be displayed in supermarkets and produce outlets.

Other recommendations to promote fresh sweet corn consumption and increase industry profits include:
- Promoting microwave cooking and ready-to-cook products (if quality can be preserved). This would help address consumers' perceptions that fresh sweet corn is inconvenient and takes too long to prepare.

- Future promotional efforts should be directed more heavily toward converting younger shoppers into life-long consumers. Good value promotions could be directed toward smaller and lower-income households, since the price of fresh sweet corn does not appear to be a significant determinant of its consumption.

- Preferences among consumers for yellow, white, and bicolor fresh sweet corn vary by race, location, and income. Promotional efforts and distributional plans should incorporate these differences.

- Consumers are generally unaware of differences in fresh sweet corn varieties, particularly "supersweet" varieties. More resources should be devoted to producing television feature stories, news releases targeted 
for newspaper food editors, consumer magazine feature stories, and a Southern Supersweet Internet website.

- Retailers should be urged to offer refrigerated unshucked fresh sweet corn in bulk displays during all seasons of the year. Bulk displays convey freshness, and refrigerated unshucked corn best preserves product quality and taste.

- The majority of consumers do not realize the importance of refrigeration and leaving the corn unshucked in maintaining sweet corn quality and taste. Consumer educational programs should stress the importance of refrigerating the corn and keeping the corn unshucked until just before cooking.

\section{References}

Degner, Robert L., Kimberly L. Morgan, Chris deBodisco, Lisa House. "Market Development Strategies for Fresh Sweet Corn Based Upon Consumer and Trade Surveys." Florida Agricultural Market Research Center, Industry Report 01-1, Institute of Food and Agricultural Sciences, University of Florida. December, 2001 http://agmarketing.ifas.ufl.edu/downloads/ sweet_corn_final_report.pdf

Florida Agricultural Statistics Service, USDA-NASS, Florida Agricultural Facts, 2002, http://www.nass.usda.gov/fl/facts/faf02/a71.htm.

USDA-AMS Fruit and Vegetable Program, Market News Branch. "Fresh Fruit and Vegetable Shipments" FVAS-4, 2000.

USDA-ERS, U.S. and State Farm Income Database, 1992-2001, http://www.ers.usda.gov/data/farmincome/ finfidmu.htm. 
Table 1. Reasons survey respondents do not buy fresh sweet corn.

\begin{tabular}{|c|c|c|}
\hline Reason & Number & Percent $^{a}$ \\
\hline Do Not Like Taste & 96 & 30 \\
\hline Preparation Time or Inconvenience & 71 & 22 \\
\hline Other & 57 & 18 \\
\hline Not Fresh & 27 & 8 \\
\hline Do Not Cook & 23 & 7 \\
\hline Prefer Canned or Frozen & 22 & 7 \\
\hline Too Messy & 21 & 7 \\
\hline Dental Problems & 16 & 5 \\
\hline Not Available & 15 & 5 \\
\hline Goes Bad & 14 & 4 \\
\hline Health, Allergy & 12 & 4 \\
\hline Do Not Eat/Do Not Buy It & 12 & 4 \\
\hline Texture, Starchy & 11 & 3 \\
\hline Price Too High & 10 & 3 \\
\hline Health, Calories & 10 & 3 \\
\hline Damaged & 7 & 2 \\
\hline Pack Too Large & 4 & 1 \\
\hline Do Not Know How to Cook & 4 & 1 \\
\hline \multicolumn{3}{|c|}{$\begin{array}{l}\text { Source: Study survey. } \\
\text { a Percentages are based on } 321 \text { respondents who do not buy fresh sweet corn. } \\
\text { There were a total of } 432 \text { responses because some respondents gave multiple } \\
\text { reasons for not buying sweet corn. }\end{array}$} \\
\hline
\end{tabular}

